\title{
Post-weaning weight gain and pregnancy rate of beef heifers bred at 18 months of age: a meta-analysis approach
}

\section{Leonardo Canali Canellas ${ }^{1}$, Júlio Otávio Jardim Barcellos ${ }^{2,5}$, Luciana Neves Nunes ${ }^{3}$, Tamara Esteves de Oliveira ${ }^{1}$, Ênio Rosa Prates $^{2}$, Daniel Chamorro Darde ${ }^{4}$}

\author{
1 Programa de Pós-Graduação em Zootecnia, Universidade Federal do Rio Grande do Sul (UFRGS), Porto Alegre, RS, Brasil. \\ 2 Departamento de Zootecnia, UFRGS. Av. Bento Gonçalves, 7712, Porto Alegre, RS, Brasil. \\ 3 Departamento de Estatística, Instituto de Matemática, UFRGS, Porto Alegre, RS, Brasil. \\ ${ }^{4}$ Curso de Graduação em Agronomia, UFRGS, Porto Alegre, Brasil. \\ 5 Pesquisador de Produtividade CNPq e Beneficiário de Auxílio Financeiro no 2842/2010 da CAPES/Brasil.
}

\begin{abstract}
The objective of this study was to evaluate, using meta-analysis, the main factors related to post-weaning body weight and weight gain that affect pregnancy rate of heifers bred at 18 months of age. Data of 1398 beef heifers from six experiments were analyzed as a set. Information related to methodology and results of each experiment were codified in Microsoft Excel spreadsheets. The independent variables analyzed were: body weight at seven months of age (BW7M), daily weight gain from seven to 12 months (DWG7-12), body weight at 12 months of age (BW12M), daily weight gain from 12 to 15 months (DWG12-15), body weight at 15 months of age (BW15M), daily weight gain from 15 to 18 months (DWG15-18), daily weight gain from 7 to 18 months (DWG7-18) and body weight at 18 months of age (BW18M). The response variable was pregnancy rate (PR). Body weight at 18 months of age and DWG7-18 showed high correlation with PR and between each other. The other variables presented low correlation with PR. Body weight at first breeding and daily weight gain from seven to 18 months are the most important variables affecting the pregnancy rate of heifers bred at 18 months of age in the autumn. Weaning weight and weight gain during intermediate steps of the post-weaning period are not good predictors of pregnancy rate. Higher pregnancy rates can be obtained provided enough post-weaning weight gain and minimum body weight at first breeding are achieved, irrespective of when weight is gained.
\end{abstract}

Key Words: body weight, mating, yearling

\section{Introduction}

Beef heifers are usually first bred at 24-26 months of age in Brazil. The main limitation of this system is the pregnancy rate in the next breeding season, which is usually low due to the high nutritional requirements of the cow at first calving in range conditions.

The main objective of breeding heifers at 18 months of age is to ensure high pregnancy rates both in the first and second breeding seasons. In this system, heifers are bred between March and May, and they calf during the next summer, at 30 months of age. Cows are then bred for the second time with 36 months, in the next spring, with their calves already weaned, which allows directing most of their energy intake to restore their body and physiological conditions, and therefore, these cows have higher probability of conceiving again.

Heifer pregnancy rate essentially depends on the previous occurrence of puberty (Short \& Bellows, 1971), which requires the combination of minimal values of two interrelated parameters: age and weight (Patterson et al., 1992). Bos taurus and Bos indicus females that achieve 60 and $65 \%$ of the mature weight estimated for their breed, respectively, tend to present higher pregnancy rates (Bolze \& Corah, 1993; NRC, 2000).

Studies have suggested that, in addition to body weight at the beginning of the breeding season, postweaning weight gain may also influence the pregnancy rate of 18-month-old heifers (Pellagio \& Capurro, 2002; Costa, 2006). These authors showed that heifers bred at similar body weight, but with higher weight gain rates at the beginning, middle, and end of the post-weaning period, presented different pregnancy rates. However, there was no agreement between the results of the different studies as to which is the most important stage.

The inconsistency betweem the results of studies evaluating the same parameters may be explained by differences in experimental conditions that normally occur, and one way to circumvent this problem is to evaluate a set of experiments with similar characteristics (Lovatto et al., 2007). 
The meta-analysis allows combining the results of independent studies to summarize the conclusions or even to draw a new conclusion (Luiz, 2002).

The objective of the present study was, using metaanalysis, to determine the main factors related to live weight and weight gain of yearling heifers that influence their pregnancy rate when bred at 18 months of age.

\section{Materials and Methods}

Combined data of 1.398 beef heifers of British (Hereford), synthetic (Braford) or zebu (Nellore) breeds were analyzed. Data were obtained from six experiments: three were published in Brazilian journals (Barcellos et al., 2006; Montanholi et al., 2004; Semmelmman et al., 2001), two in Ph.D. theses (Costa, 2006; Motta de Souza, 2009) and one in an undergraduate research project (Pellagio \& Capurro, 2002).

An online bibliographic research with the following key-words was conducted: novilhas (heifers, vaquillonas)", "recria de novilhas (rearing/replacement heifers, recria de vaquillonas)", “crescimento (growth, crecimiento)", "acasalamento aos 18 meses (18-month-old mating, entore a los 18 meses)", and "taxa de prenhez (pregnancy rate, tasa de preñez)". The undergraduate research project of Pellagio \& Capurro (2002) was also utilized. Information on the methodology and the results of each study were entered in

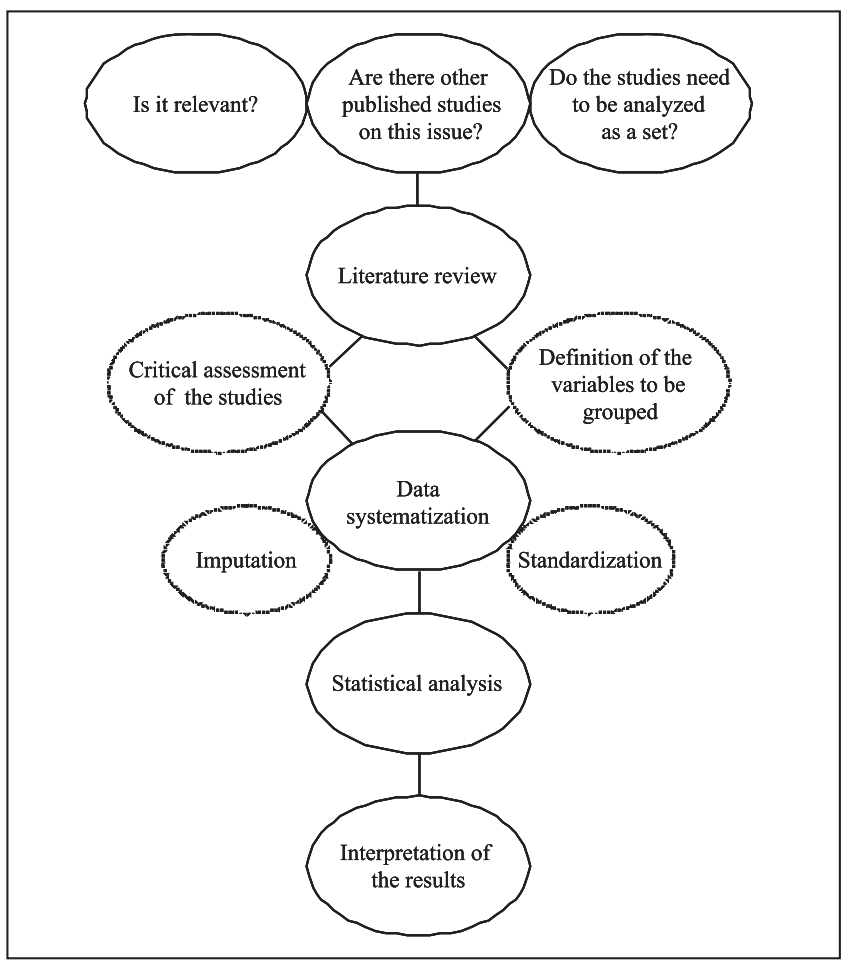

Figure 1 - Summary of the steps of the meta-analysis.
Microsoft Excel spreadsheet to systematize data. The objective of data systematization was to obtain a uniform set of information by coding data according to Author, Publication Year, Materials/Methods, and Results (measured parameters) of each study searched (Figure 1).

The database initially consisted of 11 experiments. The conditions for the permanent inclusion of the studies in the database and their joint analysis was to contain mean values for the response parameter "pregnancy rate of heifers bred at 18 months" and at least one independent variable related to the evolution of heifer post-weaning weight (body weight in intermediate growth steps or weight gain between weaning and 18 months of age).

After these conditions, only six experiments were conducted, remaining in the database and effectively used in the meta-analysis. Each experiment used a number of animals, according to the experimental design used in each study. The letter $\mathrm{N}$ used in the presentation of the results of the meta-analysis refers to the number of groups or treatments, considering all experiments. Therefore, $\mathrm{N}$ ranged between 8 and 18, according to the variable (s) contained in each experiment.

The variables used to systematize data were chosen during the review and critical analysis of the papers, resulting in nine independent variables and a response variable (pregnancy rate of heifers bred at 18 months of age, PR). The independent variables were: body weight at seven months of age (BW7M), representing calf weaning weight, in kg; daily weight gain from seven to 12 months (DWG7-12), representing daily weight gain during the winter (May to September), in kg/day; body weight at 12 months of age (BW12M), representing heifer body weight at the end of the winter and beginning of the spring, in kg; daily weight gain from 12 to 15 months (DWG12-15), representing daily weight gain during the spring (October to December), in kg/day; body weight at 15 months of age (BW15M), representing heifer body weight at the end of spring and beginning of summer, in kg; daily weight gain between 15 and 18 months (DWG15-18), representing daily weight gain during the summer (January to March), in kg/day; daily weight gain from seven to 18 months (DWG7-18), representing daily weight gain during the entire post-weaning period, that is, from weaning to breeding, in $\mathrm{kg} /$ day; and body weight at 18 months of age (BW18M), representing body weight in the beginning of the autumn breeding season, in $\mathrm{kg}$.

Not all independent variables were included in the reviewed studies. Since the experiments were independent, different variables were found, as a function of the methodology applied by the authors and of the objectives 
of the studies, resulting in blank cells in the data systematization spreadsheet. This problem was reported by Lovatto et al. (2007), who asserted that the lack of information in data sheets reduces the analytical resources of meta-analysis. The solution for this problem was to impute the missing data in each experiment and to analyze them together with the available data. In the present study, the method used was simple imputation of missing data using the mean, which was calculated based on the information contained in the experiments, except for the information of the study of Montanholi et al. (2004), which were complemented with body weight data retrieved from the dissertation (Montanholi, 2004) on which the published paper was based. The variables DWG7-18 (Costa, 2006), DWG12-15, P15M and DWG15-18 (Montanholi et al., 2004) and DWG7-18 (Semmelmann et al., 2001) were imputed.

Pearson correlation coefficients (r) were calculated for all variables. Regression models were also built using pregnancy rate as response variable and the effect of study size (number of animals used in the trial) as covariable in the model. A 5\% significance level was used as decision criterion when hypotheses were tested. The statistical analyses were carried out using SPSS statistical package (Statistical Package for the Social Sciences, version 18.0).

\section{Results and Discussion}

Daily weight gain between seven and 18 months of age (DWG7-18) was the variable that presented the highest correlation with pregnancy rate $(\mathrm{r}=0.857, \mathrm{P}<0.05)$ (Table 1).

Four groups of heifers analyzed in the different studies presented PR equal or higher than $80 \%$. Their DWG7-18 were higher than $0.400 \mathrm{~kg} /$ day, showing the importance of this parameter to achieve high PR (Figure 2). The variable DWG7-18 was also highly correlated with BW18M( $\mathrm{r}=0.981)$. These results highlight the importance of weight gain between weaning and the breeding season to allow 18-month old heifers to conceive possibly due to the influence of weight gain during this period on heifer body and reproductive development, and on heifer body weight at first breeding.

Body weight at seven months of age (BW7M) presented low correlation with both PR and DWG7-18. Based on the analysis carried out in the present study, this variable has little influence on the reproductive performance of heifers bred as yearlings. Di Marco et al. (2007) suggest that postweaning weight gain is perhaps the most important variable determining heifer body weight at mating, and may compensate low weaning weights. Working with beef heifers subjected to early or conventional weaning (average weaning weight of 91.6 and $124.5 \mathrm{~kg}$, respectively), Gottschall et al. (2006) obtained similar body weight at 18 months of age and pregnancy rates in both groups (279.2 and $278.0 \mathrm{~kg}$, and 61 and $69 \%$, respectively). This shows that similar pregnancy rates can be obtained with different weaning weights, provided post-weaning weight gain compensates that low weaning weight. It is important to highlight that weaning weight must always be related to the targeted body weight at breeding and with the time available to achieve that weight. This means that very low weaning weights demand high post-weaning weight gain, which may cause early weaning to be unfeasible from the biological or economic standpoints.

Body weight at 18 months of age (BW18M) was highly correlated $(\mathrm{r}=0.681, \mathrm{P}<0.05)$ with pregnancy rate (Table 1$)$. This result is consistent with the findings of several authors (Bolze \& Corah, 1993; Lynch et al., 1997; Patterson et al., 1992; Lamb, 2006) that when the minimal critical body weight is achieved (60\% for Bos taurus and 65\% for Bos indicus), heifers are ready to conceive. Working with data of heifers bred at 14 months of age, Bittencourt et al. (2005) estimated that $73.6 \%$ of the variation in the probability of pregnancy could be explained by body weight at the beginning of the breeding season, and stressed the relation of this parameter with heifer pregnancy rate.

Table 1 - Correlation between independent variables and the response variable pregnancy rate (PR) of heifers bred at 18 months of age

\begin{tabular}{llrr}
\hline Independent variables & $\mathrm{N}$ & \multicolumn{2}{c}{ Response variable (PR) } \\
\cline { 2 - 4 } & & Correlation coefficient (r) & Significance level (p) \\
\hline Body weight at seven months of age & 11 & 0.153 & 0.653 \\
Daily weight gain from seven to 12 months & 11 & -0.008 & 0.983 \\
Body weight at 12 months of age & 14 & 0.124 & 0.672 \\
Daily weight gain from 12 to 15 months & 06 & 0.171 & 0.244 \\
Body weight at 15 months of age & 08 & -0.059 & 0.685 \\
Daily weight gain from 15 to 18 months & 08 & 0.857 & 0.890 \\
Daily weight gain from seven to 18 months & 11 & 0.681 & $0.001^{*}$ \\
Body weight at 18 months of age & 18 & & $0.002^{*}$ \\
\hline
\end{tabular}




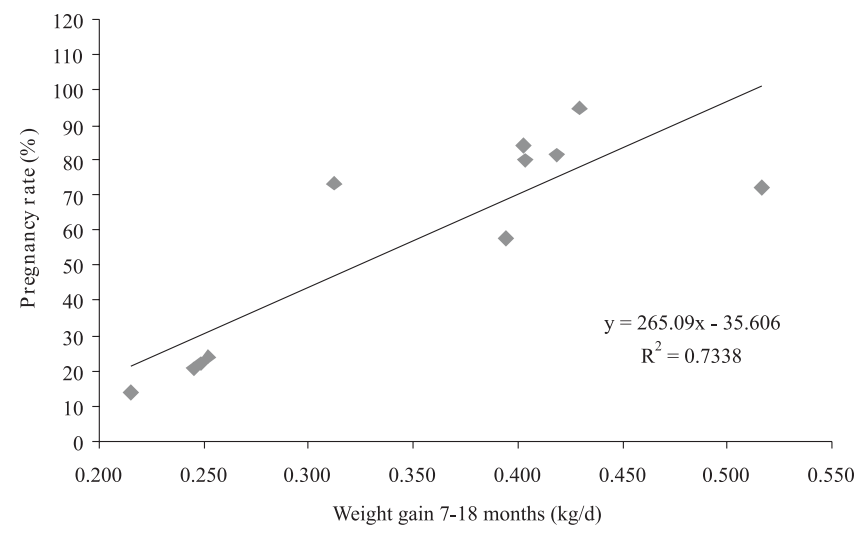

Figure 2 - Scatter plot relating daily weight gain between seven and 18 months with the pregnancy rate of the different analyzed groups $(\mathrm{N}=11)$

Among the analyzed heifer groups, those that presented the highest pregnancy rates were the ones with BW18M higher than $300 \mathrm{~kg}$. This shows a trend to increase PR as body weight at the beginning of the breeding season increases (Figure 3).

Pregnancy rates higher than $80 \%$ were obtained by heifer groups with BW18M between 305 and $320 \mathrm{~kg}$. The heifers used in the experiments belonged to British breeds (four experiments with Hereford heifers), British and synthetic breeds (one experiment using Hereford and Braford heifers) or Zebu breeds (one experiment with Nellore heifers), in which the mature female body weight ranges between 440 and $500 \mathrm{~kg}$ (Barcellos, 2001; Lamb, 2006; Rosa et al., 2001). Therefore, the minimal critical body weight for the heifers used in the reviewed studies should be approximately $290-320 \mathrm{~kg}$, confirming the assertion that, in order to obtain high pregnancy rates at first breeding, heifers must achieve at least 60 or $65 \%$ of mature cow body weight of their respective breed.

Barcellos et al. (2000) found pregnancy rates of 35.9 and $57.1 \%$ when heifers weighed 261 and $283 \mathrm{~kg}$, respectively, at 18 months of age (beginning of the breeding season). Moreover, those authors found significant differences in the average body weight at 18 months between heifers that conceived (300 kg) and those that did not conceive (268 kg), suggesting that the main limitation for breeding yearling heifers is body weight at the beginning of the breeding season.

Semmelmman et al. (2001) attributed the low pregnancy rates (13.8-24.2\%) obtained in heifers bred at 18 months of age to their insufficient body weight at the beginning of the breeding season. In an experiment comparing the pregnancy rate of light (264 kg) or heavy (301 kg) 18-monthold heifers, Barcellos et al. (2006) obtained pregnancy rates of 26.7 and $73.3 \%$, respectively, demonstrating that heifers

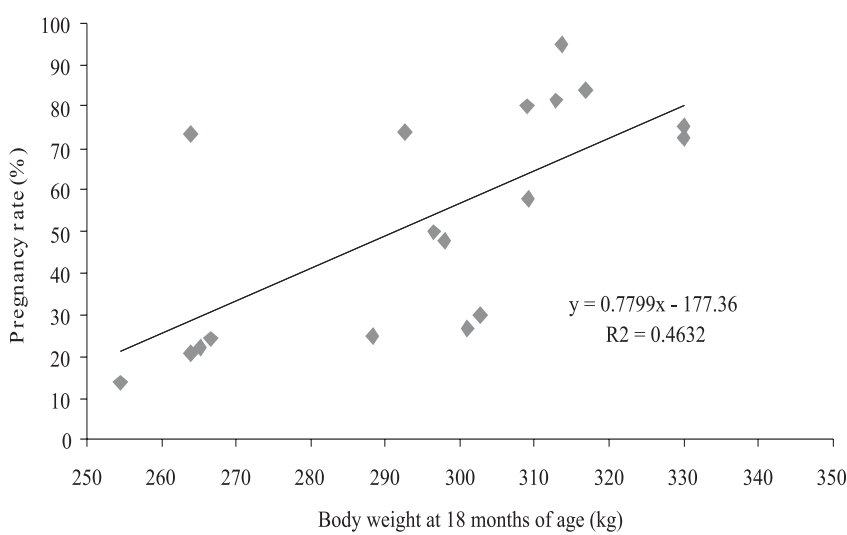

Figure 3 - Scatter plot relating body weight at 18 months of age with pregnancy rate of the different groups of heifers analyzed $(\mathrm{N}=18)$.

that were heavier at breeding tend to present higher pregnancy rates.

The variables DWG7-12, BW12, DWG12-15, BW15, and DWG15-18 did not present any significant correlation with $\mathrm{PR}$, indicating that these are not the best parameters to determine the pregnancy rate of heifers bred as yearlings. The analysis of these variables as a set showed different results, in some aspects, than those individually found in some experiments. In the study of Pellagio \& Capurro (2002), the authors concluded that weight gain during winter (DWG7-12) was the main variable that determined the PR of heifers bred as yearlings, regardless of body weight at 18 months of age, i.e., at the beginning of the breeding season. Costa (2006), on the other hand, concluded that the effect of weight gain on the pregnancy rate of heifers bred at 18 months of age is higher for the period of seven to 12 months, and from 12 to 15 months, than for the entire rearing period. The inconsistencies observed in experiments, and the joint data analyses were possibly due to specific experimental conditions, stressing the importance of performing more comprehensive analysis, such as metaanalysis, which allows reaching more reliable conclusions, based on a higher amount of information.

Other evaluated studies confirm the results obtained in the meta-analysis. Semmelmann et al. (2001) concluded that pregnant heifers gained more weight during rearing and were heavier at the beginning of the breeding season. The study conducted by Motta de Souza (2009) demonstrated that the higher weight gain from 15 to 18 months of age, resulting from better feeding management practices, promoted higher body weight at the beginning of the breeding season and higher pregnancy rate.

Montanholi et al. (2004) concluded that the reproductive tract of heifers managed to achieve higher 
weight gain at the end of the rearing period was more mature; however, the authors did not find any differences between pregnancy rates of 30, 48 and $50 \%$ for weight gains of $0.595,0.637$ and 0.723 , respectively. Nevertheless, those authors suggested a trend for higher pregnancy rate in heifers presenting a more mature reproductive tract, which was a result of higher weight gain during rearing.
The results of the present study showed that metaanalysis can generate both convergent and divergent results in relation to the individual experiments (Table 2), stressing the risks of extrapolating the results of the statistical analysis of a single experiment. This means it is essential to comply with the research principle that determines that the results of an experiment can only be applied to very similar experimental conditions of another study.

Table 2 - Main variables determining pregnancy rate in each individual experiment and in the meta-analysis using all six experiments

\begin{tabular}{ll}
\hline Experiment & Main variables \\
\hline Barcellos et al. (2006) & BW18M \\
Pellagio \& Capurro (2002) & DWG7-12 \\
Costa (2006) & DWG7-12 and DWG12-15 \\
Montanholi et al. (2004) & DWG12-15 and DWG15-18 \\
Motta de Souza (2009) & DWG15-18 and BW18M \\
Semmelmann et al. (2001) & BW18M \\
Meta-analysis of all six experiments & DWG 7-18 and BW18M
\end{tabular}

\section{Conclusions}

Higher pregnancy rates at 18 months of age can be obtained provided enough post-weaning weight gain and minimum body weight at first breeding are achieved, regardless of when weight is gained.

\section{References}

BARCELlos, J.O.J. Puberdade em novilhas Braford: desenvolvimento corporal e relações endócrinas. 2001. 164f. Tese (Doutorado em Zootecnia) - Faculdade de Agronomia/ Universidade Federal do Rio Grande do Sul, Porto Alegre.

BARCELlOS, J.O.J.; PATIÑO, H.O.; PRATES, E.R. et al. Carga animal pós-desmama e desempenho reprodutivo de novilhas de corte acasaladas aos 18 meses de idade. In: REUNIÃO ANUAL DA SOCIEDADE BRASILEIRA DE ZOOTECNIA, 37., 2000, Viçosa, MG. Anais... Viçosa, MG: Sociedade Brasileira de Zootecnia, 2000. (CD-ROM).

BARCELLOS, J.O.J.; SILVA, M.D.; PRATES, E.R. et al. Taxas de prenhez em novilhas de corte acasaladas aos 18 e 24 meses de idade. Arquivo Brasileiro de Medicina Veterinária e Zootecnia, v.58, n.6, p.1168-1173, 2006.

BITTENCOURT, H.R.; GOTTSCHALL, C.S.; SANT’ANA, M.F. Um modelo alternativo para predição da probabilidade de prenhez em função do peso no início do acasalamento. Arquivos de Ciências Veterinárias e Zoologia da Unipar, v.8, n.2, p.99-104, 2005.

BOLZE, R.; CORAH, L.R. Selection and development of replacement heifers. Manhattan: Kansas State University Cooperative. Extension Service, 1993. 10p.

COSTA, E.C. Crescimento pós-desmama e taxa de prenhez de novilhas de corte acasaladas aos 18 meses de idade. 2006. 154f . Tese (Doutorado em Zootecnia) - Faculdade de Agronomia/ Universidade Federal do Rio Grande do Sul, Porto Alegre.

DI MARCO, O.N.; BARCELLOS, O.J.; COSTA, E.C. Crescimento de bovinos de corte. Porto Alegre: UFRGS, 2007. 276p.
GOTTSCHALL, C.S.; LOURENZEN, G.O.; FERREIRA, E.T. et al. Desempenho de novilhas acasaladas com 18 meses provenientes de desmame precoce ou convencional. Veterinária em foco, v.4, n.1, 2006.

LAMB, C. Entendendo os efeitos da nutrição na reprodução de vacas de corte. In: NOVOS ENFOQUES NA PRODUÇÃO E REPRODUÇÃO DE BOVINOS, 10., 2006, Uberlândia. Anais... Uberlândia, 2006. p.139-151.

LOVATTO, P.A.; LEHNEN, C.R.; ANDREATTA, I. et al. Metaanálise em pesquisas científicas - enfoque em metodologias. Revista Brasileira de Zootecnia, v.36, p.285-294, 2007 (supl. especial).

LUIZ, A.J.B. Meta-análise: Definição, aplicações e sinergia com dados espaciais. Cadernos de Ciência \& Tecnologia, v.19, n.3, p.407-428, 2002.

LYNCH, J.M.; LAMB, G.C.; MILLER, B.L. et al. Influence of timing of gain on growth performance of beef replacement heifers. Journal of Animal Science, n.75, p.1715-1722, 1997.

MONTANHOLI, Y.R. Efeitos do ganho de peso dos 13 aos 18 meses de idade sobre o desempenho reprodutivo de novilhas de corte acasaladas ao sobreano no outono. 2004 94f. Dissertação (Mestrado em Zootecnia) - Universidade Federal do Rio Grande do Sul, Porto Alegre.

MONTANHOLI, Y.R.; BARCELLOS, J.O.J.; BORGES, J.B. et al. Ganho de peso na recria e desempenho reprodutivo de novilhas acasaladas com sobreano. Pesquisa Agropecuária Brasileira, v.39, n.12, 2004.

MOTTA DE SOUZA, A.N. Uso de pastagens de gramíneas de estação quente na recria de novilhas de corte. 2009. 137f. Tese (Doutorado em Zootecnia) - Universidade de Santa Maria, Santa Maria.

NATIONAL RESEARCH COUNCIL - NRC. Nutrient requeriments of beef cattle. 7. rev. ed. Washington: National Academy Press, 2000. 248p.

PATTERSON, D.J.; PERRY, R.C.; KIRAKOFE, G.H. et al. Management considerations in heifer development and puberty. Journal of Animal Science, v.70, n.12, p.4018-4035, 1992.

PELLAGIO, B.M; CAPURRO, C.F.F. Factores que afectan la fertilidad de vaquillonas Hereford y Brahman $x$ Hereford 
en el servicio de 18 meses de edad. 2002. 132f. Tesis (Graduacíon) - Facultad de Agronomía/Universidad de la República, Montevideo.

ROSA, A.N.; LÔBO, R.B.; OLIVEIRA, H.N. et al. Peso adulto de matrizes em rebanhos de seleção da raça Nelore no Brasil. Revista Brasileira de Zootecnia, v.30, n.3, p.1027-1036, 2001 (supl. 1).
SEMMELMANN, C.E.N.; LOBATO, J.F.P.; ROCHA, M.G. Efeito de sistemas de alimentação no ganho de peso e desempenho reprodutivo de novilhas Nelore acasaladas aos 17-18 meses. Revista Brasileira de Zootecnia, v.30, n.3, p.835-843, 2001. SHORT, R.E.; BELLOWS, R.A. Relationships among weight gains, age at puberty and reproductive performance in heifers. Journal of Animal Science, n.32, p.127-131, 1971. 